\title{
LAJU PERTUMBUHAN RUMPUT LAUT (Kappaphycus alvarezii) DENGAN MENGGUNAKAN BIBIT PADA LOKASI YANG BERBEDA
}

\author{
Frederik Dony Sangkia \\ Program Studi Budidaya Perairan, Universitas Muhammadiyah Luwuk \\ Email: fd.sangkia@gmail.com
}

\begin{abstract}
ABSTRAK
Rumput laut merupakan salah satu sumberdaya pesisir yang mempunyai nilai ekonomis yang cukup tinggi dan merupakan salah satu komoditas ekspor andalan yang permintaannya tinggi di pasar dunia, sehingga kemampuan produksinya harus terus ditingkatkan guna memenuhi kebutuhan konsumen yang setiap tahunnya mengalami kekurangan. Penelitian ini bertujuan untuk menelaah laju pertumbuhan rumput laut $K$. alvarezii yang optimal dengan menggunakan bibit pada lokasi yang berbeda. Kegunaan penelitian ini diharapkan dapat menjadi bahan informasi pembudidaya dalam meningkatkan produksi rumput laut $K$. alvarezii. Penelitian ini dilaksanakan pada bulan Juni hingga Juli 2014 di perairan Pulau Limbo, Kecamatan Bobong, Kabupaten Taliabu, Provinsi Maluku Utara. Berdasarkan hasil penelitian yang dilaksanan di kelurahan Panau dapat ditarik kesimpulan bahwa analisis ragam menunjukkan bahwa ada perbedaan terhadap asal bibit yang berbeda. Perlakuan A memberikan pertumbuhan rumput laut yang lebih tinggi dibandingkan pertumbuhan perlakuan B dan $\mathrm{C}$.
\end{abstract}

Kata kunci : Rumput laut, Bibit, Laju, Pertumbuhan

\section{PENDAHULUAN}

Rumput laut merupakan salah satu sumberdaya pesisir yang mempunyai nilai ekonomis yang cukup tinggi dan merupakan salah satu komoditas ekspor andalan yang permintaannya tinggi di pasar dunia, sehingga kemampuan produksinya harus terus ditingkatkan guna memenuhi kebutuhan konsumen yang setiap tahunnya mengalami kekurangan (Dawes, 1981).

Namun keberhasilan suatu usaha budidaya rumput laut sangat tergantung faktor-faktor yang mempengaruhi baik faktor eksternal yaitu terkait pemilihan lokasi yang sesuai dengan jenis rumput laut juga faktor-faktor yang erat hubungannya dengan karakteristik lingkungan perairan setempat maupun faktor internal terkait asal thallus, bobot bibit dan jarak tanam yang digunakan (Prihaningrum, Meiyana dan Evalawati, 2001).

Perairan pantai mempunyai arti penting bagi masyarakat setempat dengan peranannya sebagai sumber mata pencaharian dalam bidang perikanan, salah satunya pembudidayaan rumput laut yang merupakan mata pencaharian tambahan. Hanya dengan menggunakan peralatan sederhana dan tenaga yang relatif lebih kecil, budidaya rumput laut dapat memperoleh hasil yang lumayan disamping juga pekerjaan utama menangkap ikan (Kordi, 2008). Kondisi perairan pantai di Desa Selati, Desa Nggele dan Desa Nambeang di Kecamatan Taliabu Kabupaten Sula merupakan daerah produksi budidaya rumput laut. 
Namun demikian sistem budidaya yang dilakukan belum dapat mencapai produksi yang diharapkan. Kendala utama yaitu pengadaan bibit yang memiliki kualitas yang baik masih diharapkan (Kordi, 2008). Untuk menghasilkan suatu kualitas rumput laut yang baik maka perlu dilakukan penelitian terkait hubungan antara asal bibit yang berbeda dari lokasi yang berbeda khususnya Desa Selati, Desa Nggele dan Desa Nambeang di Kecamatan Taliabu Kabupaten Sula, sehingga dapat ditentukan perlakuan yang baik untuk daerah asal bibit dan faktorfaktor yang paling berpengaruh terhadap pertumbuhan rumput laut Kappapycus alvarezii. Penelitian ini bertujuan untuk menelaah laju pertumbuhan rumput laut $K$. alvarezii yang optimal dengan menggunakan bibit pada lokasi yang berbeda. Kegunaan penelitian ini diharapkan dapat menjadi bahan informasi pembudidaya dalam meningkatkan produksi rumput laut $K$. alvarezii.

\section{METODOLOGI PENELITIAN}

Waktu dan Tempat

Penelitian ini dilaksanakan pada bulan Juni hingga Juli 2014 di perairan Nggele, Kecamatan Taliabu, Kabupaten Sula, Provinsi Maluku Utara.

Alat dan Bahan

Alat dan bahan yang akan digunakan dalam penelitian ini tertuang pada Tabel 1 dan Tabel 2.

Tabel 1. Alat-Alat Penelitian

\begin{tabular}{lll}
\hline No & Alat & Kegunaan \\
\hline 1. & Secchi disck & Untuk mengukur kecerahan \\
2. & Termometer & Untuk mengukur suhu air \\
3. & Refraktometer & Untuk mengukur kadar garam \\
4. & Kertas pH & Untuk mengukur pH air \\
5 & Pelampung Induk & Untuk mengapungkan tali induk \\
6 & Pelampung Ris & Untuk mengapungkan tali ris \\
7 & Pemberat & Untuk pemberat tali induk \\
8 & Layangan Arus & Untuk mengukur kecepatan arus \\
9 & Timbangan & Untuk menimbang rumput laut \\
\hline
\end{tabular}

Tabel 2. Bahan-Bahan Penelitian

\begin{tabular}{lll}
\hline No & Bahan & Kegunaan \\
\hline 1 & Rumput Laut (K. alvarezii) dari Desa & Organisme Uji \\
& Selati, Desa Nggele dan Desa & \\
& Nambeang di Kec. Taliabu Kab. Sula & \\
2 & Tali Rapia & $\begin{array}{l}\text { Untuk mengikat rumput } \\
\text { laut }\end{array}$ \\
\hline
\end{tabular}

\section{Rancangan Percobaan}

Rancangan yang digunakan dalam penelitian ini adalah Rancangan Acak Lengkap (RAL) dengan tiga perlakuan dan tiga ulangan, sehingga jumlah unit percobaan adalah sembilan satuan percobaan.

Perlakuan A = Bibit Rumput Laut dari Desa NggeleKec. Taliabu Kab. Sula 
Perlakuan B = Bibit Rumput Laut dari Desa Selati Kec. Taliabu Kab. Sula Perlakuan C = Bibit Rumput Laut dari Desa Nambeang Kec. Taliabu Kab. Sula

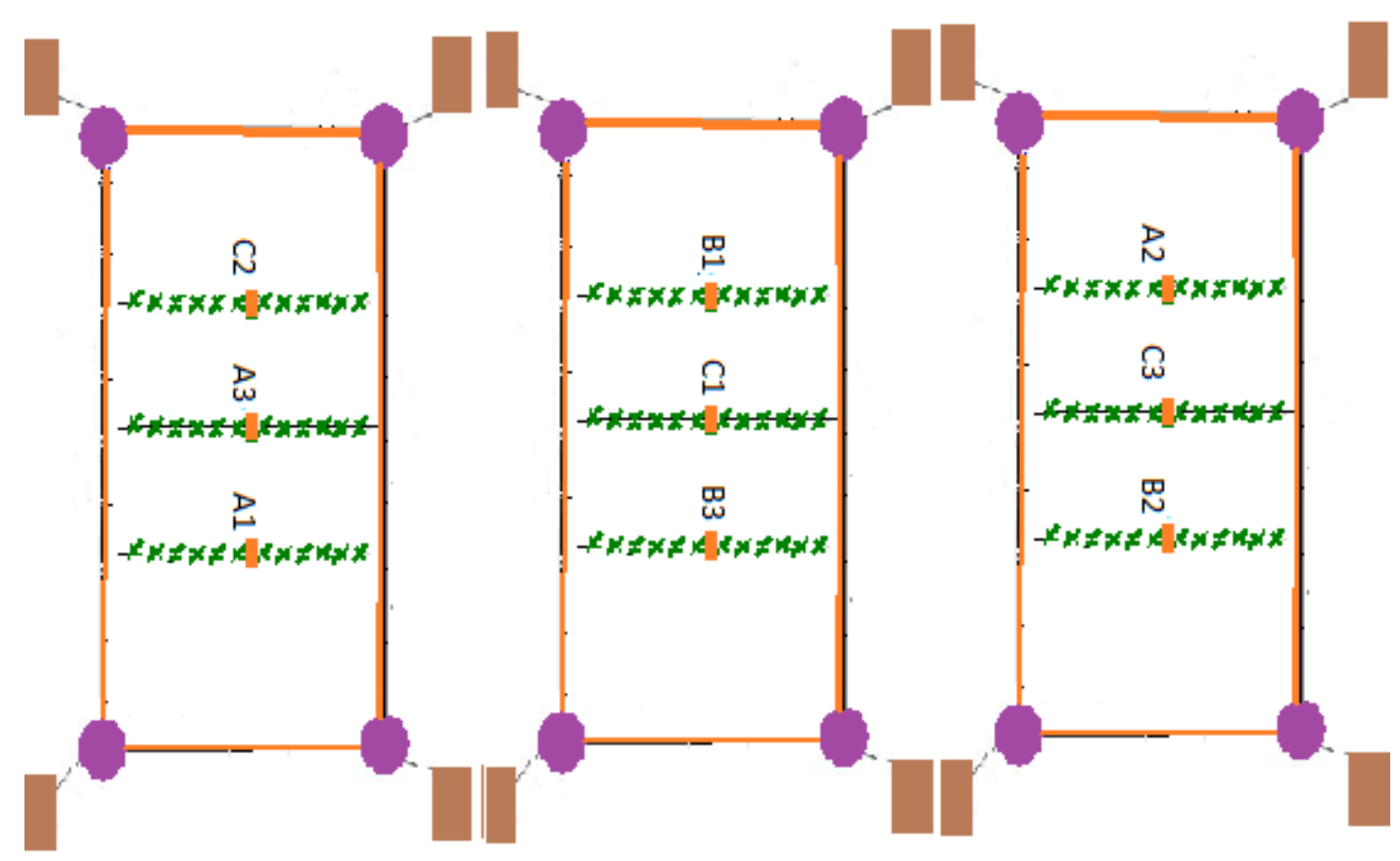

Keterangan gambar:

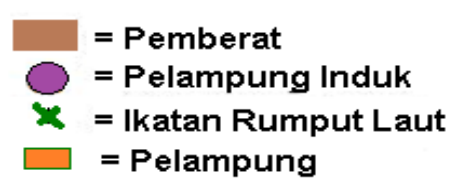

Gambar 1. Penempatan Unit-Unit Percobaan

\section{Prosedur Penelitian}

1. Tahap Persiapan

- Menyiapkan alat dan bahan yang akan digunakan dalam penelitian

- Menyiapkan organisme uji dari lokasi yang berbeda dan menimbangnya

- Mengikat organisme uji pada tali ris masing-masing 100 gram sebanyak 12 ikatan, dimana setiap ikatan dengan jarak $25 \mathrm{~cm}$.

2. Tahap Pelaksanaan

- Menebar organisme uji dengan menggunakan metode long line

- Mengapungkan organisme uji dengan cara diikatkan pada pelampung dari botol atau pelampung khusus pada tali ris sesuai dengan denah percobaan

- Melakukan pengamatan organisme uji setiap hari, sedangkan penimbangan organisme uji dilakukan setiap 2 minggu sekali.

- Melakukan pengukuran kualitas air. 


\section{Parameter yang Diamati}

Parameter yang diamati meliputi laju pertumbuhan spesifik harian, salinitas, suhu, arus, kecerahan dan kedalaman.

1. Laju Pertumbuhan Spesifik Harian

Untuk mengetahui laju pertumbuhan spesifik harian rumput laut maka digunakan rumus (Dawes et al., 1994):

$$
\begin{aligned}
\mathrm{SGR} & =\frac{\mathrm{Ln} \mathrm{Wt}-\mathrm{Ln} \text { Wo }}{\mathrm{t}} \times 100 \% \\
& \text { Dimana: } \\
\mathrm{SGR} & =\text { Laju pertumbuhan spesifik }(\%) \\
\mathrm{Wt} & =\text { Bobot rumput laut pada waktu } \mathrm{t}(\mathrm{g}) \\
\mathrm{Wo} & =\text { Bobot rata-rata bibit pada waktu awal }(\mathrm{g}) \\
\mathrm{t} & =\text { Periode pengamatan (hari) }
\end{aligned}
$$

\section{Kualitas Air}

Data kualitas air meliputi pengukuran suhu, salinitas, kecepatan arus dan kecerahan. Pengukuran salinitas dan suhu dilakukan setiap hari yaitu pagi pukul 07.00 Wita dan sore hari pukul 17.00 Wita. Pengukuran kecepatan arus dan kecerahan dilakukan setiap minggu.

\section{Analisa Data}

Untuk mengetahui pengaruh perlakuan digunakan Analisis Rą (Anova) dengan menggunakan program SPSS versi 19 (Statistical Package Social Sciences). Bila terjadi perbedaan di antara perlakuan dilanjutkan dengan uji BNT atau LSD (Gaspersz,1994).

\section{HASIL DAN PEMBAHASAN}

\section{Pertumbuhan Spesifik Harian}

Hasil pengamatan terhadap pertumbuhan spesifik harian setiap

\begin{tabular}{|c|c|}
\hline $\begin{array}{l}\text { A (Bibit Rumput Laut dari Desa } \\
\text { Nggele Kec. Taliabu Kab. Sula) }\end{array}$ & $2,63 \pm 0,16^{\mathrm{a}}$ \\
\hline $\begin{array}{l}\text { B (Bibit Rumput Laut dari Desa } \\
\text { Selati Kec. Taliabu Kab. Sula) }\end{array}$ & $1,53 \pm 0,30^{\mathrm{b}}$ \\
\hline $\begin{array}{l}\text { C (Bibit Rumput Laut dari Desa } \\
\text { Nambeang Kec. Taliabu } \\
\text { Kab.Sula) }\end{array}$ & $3,06 \pm 0,28^{\mathrm{ac}}$ \\
\hline
\end{tabular}
pengamatan terlihat pada (Tabel 3).

Tabel 3. Rata-Rata Pertumbuhan Spesifik Harian Selama Penelitian

$$
\text { Perlakuan }
$$

$$
\overline{(\mathbf{X} \pm \text { SD) }}
$$


Tabel 3 di atas menunjukkan bahwa rata-rata pertumbuhan spesifik harian tertinggi selama penelitian yaitu perlakuan A $(2,63 \pm 0,16)$ selanjutnya diikuti oleh perlakuan $\mathrm{B}(1,53 \pm 0,30)$ dan perlakuan $\mathrm{C}(3,06 \pm 0,28)$. Tingginya pertumbuhan rumput laut terhadap perlakuan $\mathrm{C}$ diduga karena bibit yang terdapat di Desa Nambeang lebih baik dari bibit yang berasal dari Desa Nggele dan Desa Selati, selain itu diduga kondisi rumput laut pada perlakuan $\mathrm{C}$ sudah beradaptasi dengan lingkungan perairan sedangkan yang lainnya masih menyesuaikan diri dengan kondisi perairan budidaya rumput laut. Menurut Winarno (1990), rumput laut sangat dipengaruhi oleh kondisi perairan seperti: ombak diperlukan oleh rumput laut untuk mempercepat zat-zat makanan ke dalam sel tanaman, sedangkan arus diperlukan untuk pertumbuhan karena arus dapat membawa zatzat makanan bagi rumput laut dan menghanyutkan kotoran-kotoran yang melekat pada rumput laut, sehingga rumput laut yang mendapat suplai nutrien atau makanan yang banyak akan mempercepat pertumbuhannya.

Berdasarkan analisis ragam terhadap pertumbuhan spesifik harian (Lampiran 4), diperoleh bahwa metode asal bibit rumput laut yang berbeda dapat memberikan pengaruh $(\mathrm{P}<0,01)$ terhadap pertumbuhan. Hasil uji BNT menunjukkan bahwa perlakuan $\mathrm{A}$ berbeda $(\mathrm{P}<0,05)$ terhadap perlakuan $\mathrm{B}$, tetapi tidak berbeda $(\mathrm{P}<0,01)$ dengan perlakuan $\mathrm{C}$, sedangkan perlakuan $\mathrm{B}$ berbeda $(\mathrm{P}<0,01)$ dengan perlakuan $\mathrm{C}$. Berdasarkan hal tersebut diperoleh bahwa asal bibit rumput laut yang berbeda dalam setiap perlakuan memberikan pengaruh terhadap pertumbuhan rumput laut. Hal ini diduga bahwa asal bibit rumput laut yang berbeda sangat ditentukan oleh kualitas perairan lokasi pemeliharaan karena perairan mengandung unsur-unsur hara yang dibutuhkan oleh rumput laut. Disamping itu secara teknis menentukan kualitas rumput laut. Menurut Poncomulyo (2006), pertumbuhan rumput laut $K$. alvarezii dapat berkembang dengan optimal bila kondisi perairan sangat baik dan sesuai bagi organisme yang dipelihara. Sedangkan menurut Hidayat (1994), apabila terjadi penurunan salinitas air laut pada lokasi budidaya maka akan berakibat menurunnya mutu rumput laut yang dapat menyebabkan sel tanaman banyak yang rusak sehingga berdampak terhambatnya pertumbuhan rumput laut yang dibudidayakan.

\section{Kualitas Air}

Berdasarkan hasil pengamatan selama penelitian didapatkan pengukuran tentang kualitas air dimana parameter yang diamati yaitu suhu, salinitas dan $\mathrm{pH}$ terlarut tertera pada Tabel 4 di bawah ini :

Tabel 4 . Hasil Rata-Rata Pengukuran Parameter Kualitas Air Selama Penelitian

\begin{tabular}{|c|c|c|c|c|c|c|c|}
\hline \multirow[t]{3}{*}{ No. } & \multirow{3}{*}{$\begin{array}{l}\text { Parameter } \\
\text { yang Diamati }\end{array}$} & & \multicolumn{5}{|c|}{ Rata-Rata Parameter Selama Penelitian } \\
\hline & & & $\mathrm{A}$ & & $\mathrm{B}$ & & $\mathbf{C}$ \\
\hline & & Pagi & Sore & Pagi & Sore & pagi & Sore \\
\hline 1 & Suhu $\left({ }^{0} \mathrm{C}\right)$ & 28,05 & 27,9 & 27,85 & 28,12 & 28,1 & 28,1 \\
\hline 2 & Salinitas $(\% 0)$ & 30,1 & 30,1 & 30,42 & 30,48 & 30,47 & 30,46 \\
\hline 3 & $\mathrm{pH}$ & 8,7 & 8,7 & 8,7 & 8,8 & 8,7 & 8,5 \\
\hline
\end{tabular}




\section{Suhu}

Tabel 4 di atas menunjukkan bahwa kisaran suhu yang diperoleh selama penelitian berkisar $27,9-28,12^{\circ} \mathrm{C}$. Kisaran suhu tersebut masih memungkinkan Kappapicus alvarezii untuk berkembang dengan baik. Hal ini sesuai dengan pernyataan Aslan (1991), K. alvarezii masih bisa berkembang dengan baik pada suhu yang berkisar $27^{\circ} \mathrm{C}-30^{\circ} \mathrm{C}$. Suhu air laut di lokasi budidaya meskipun pengaruhnya tidak terlalu besar bagi pertumbuhan rumput laut akan tetapi perbedaan temperatur air yang terlalu besar antara siang dan malam hari dapat menghambat pertumbuhan rumput laut.

\section{Salinitas}

Tabel 4 di atas didapatkan bahwa kisaran salinitas di perairan lokasi penelitian yang diukur setiap hari yaitu pagi dan sore adalah 30,1 - 30,48\% . Nilai kisaran salinitas yang didapatkan selama penelitian berada pada kisaran yang sesuai untuk kehidupan dan pertumbuhan rumput laut $K$. alvarezii. Hal ini sesuai dengan pernyataan Aslan (1991), K. alvarezii dapat tumbuh dengan normal pada kisaran $15-38 \%$ o dengan nilai optimum 25\%o. Salinitas mempunyai arti yang sangat penting dalam usaha budidaya rumput laut, oleh karena itu apabila salinitas air laut menurun secara drastis akibat pasokan air tawar dalam hal ini curah hujan maka akan berakibat menurunnya mutu rumput laut, hal ini menyebabkan banyak sel tanaman yang rusak (Hidayat, 1994).

\section{3. pH}

Tabel 4 di atas dapat dilihat bahwa kisaran $\mathrm{pH}$ selama penelitian yang diukur pada pagi dan sore yaitu $8,5-8,8$. Nilai kisaran $\mathrm{pH}$ ini sangat mendukung $K$. alvarezii untuk tumbuh dan berkembang secara optimal. Hal ini sesuai dengan pernyataan Aslan (1991), rumput laut masih dapat tumbuh dan berkembang dengan optimal pada kisaran $\mathrm{pH} 8$ - 8,9.

\section{KESIMPULAN DAN SARAN \\ Kesimpulan}

Berdasarkan hasil penelitian yang dilaksanan di kelurahan Panau dapat ditarik kesimpulan sebagai berikut :

1. Berdasarkan analisis ragam menunjukkan bahwa ada perbedaan terhadap asal bibit yang berbeda.

2. Perlakuan A memberikan pertumbuhan rumput laut yang lebih tinggi dibandingkan pertumbuhan perlakuan B dan C

\section{Saran}

Berdasarkan hasil penelitian yang dilakukan, maka disarankan Sebaiknya menggunakan asal bibit yang berasal dari daerah tempat budidaya untuk meningkatkan pertumbuhan rumput laut. 


\section{DAFTAR PUSTAKA}

Aditya, T.W., P. Yuwan dan Sudjiharno, 2001, Pemilihan Lokasi Teknologi Budidaya Rumput Laut (Kappaphycus alvarezii). Petunjuk Teknis Departemen Kelautan dan Perikanan. Direktorat Jenderal Perikana Budidaya. Hlm 16-22.

Afrianto, E dan E. Liviawaty,1993. Budidaya Laut dan Cara Pengolahannya. Bharata. Jakarta. 60-64 hal.

Anggadiredja, J.T., Zatnika, A., Purwanto,H., dan Istini,S., 2006. Rumput Laut (Pembudidayaan, pengolahan, dan Pemasaran Komoditas Perikanan Potensial). Penebar Swadaya. Jakarta

Ask E.L., Azanza R.V. 2002. Advances in cultivation technology of commercial eucheumatoid species, a review with suggestions for future research. Aquakultur. 206: 257-277.

Aslan, L. M., 1997. Budidaya Rumput Laut. Edisi Revisi. Kanisius. Yogyakarta.

A/S Kobenhvns Pektifabrik. 1978. Carrageenan. Lilleskensved. Denmark. p156157.

Dahuri, R. J., Rais, S.P., Ginting dan M.J. Sitepu., 1996. Pengelolaan Sumberdaya Wilayah Pesisir dan Lautan Secara Terpadu. Pradnya Paramita. Jakarta. 58$65 \mathrm{hlm}$.

Darmayasa, I. G.P., 1988. Studi Perbandingan Laju Pertumbuhan Algae Merah Eucheuma spinosum (L).J. Pada Kedalaman yang Berbeda di Nusa Dua Bali. Karya Ilmiah. Fakultas Perikanan IPB. Bogor. http://www. Iptek.net.id//ttg/artlkp/artikel. $15 \mathrm{hlm}$.

Dawes, C. J. 1981. Marine Botany. Jhon Wiley \& Sons, Inc. 229 hal

Dawes, C.J., Lluis, A.O. Trono, G.C., 1994. Laboratory and Field growth studies of commercial stains of Eucheuma denticulatus and Kappaphycus alvarezii in the Philippines. Applied Phycology. 6: 21-24.

Gaspersz .V., 1994., Metode Perancangan Percobaan ; Untuk Ilmu - Ilmu Pertanian, Ilum - Ilmu Tekhnik dan Biologi. CV. Armico. Bandung. hlm 8-13.

Heddy, 2001. Ekofisiologi Tumbuhan, Suatu Kajian Kuantitatif Pertumbuhan Tanaman. PT Raja Grafika, Yogyakarta.

Indriani H dan Sumiarsih E, 1991. Rumput Laut. Jakarta

Indriani, H., Sumiarsih, E., 2003. Budidaya, Pengolahan, dan Pemasaran Rumput laut. Anggota Ikapi. PT. Penebar swadaya. Jakarta. Hlm 45-65.

Kordi, M., G. 2008. Budidaya Perairan. Buku Kesatu. PT. Citra Aditya Bakti. Bandung. 444 hal.

Nybakken, A.j., 1992. Biologi Laut; Suatu Pendekatan Ekologis (Terjemahan M.Edman; D. Bingen; Koesobiono) PT. Gramedia Pustaka. Jakarta. Hlm 2025.

Prasetyaningrum A. dan A. Purbasari, (2002), " Ekstraksi Alginat dari Rumput Laut dan Aplikasinya pada Industri ", vol. 6, No. 2, Teknik Kimia Universitas Diponegoro, Semarang.

Prihaningrum, A., M. Meiyana dan Evalawati. 2001, Biologi Rmput laut; Teknologi Budidaya Rumput Laut (Kappaphycus alvarezii). Petunjuk 
Tekhnis. Departemen Kelautan dan Perikanan. Direktorat Jenderal Perikanan Budidaya. Balai Budidaya Laut. Lampung.

Rasjid, F., M. Firdaus., S. Pudu., Dahya., Idris., Herman dan Subandi., 2000. Budidaya rumput laut (Eucheuma cottonii) Dengan Sistem Rakit Cara Tanam Legowo 6. Balai Pengkajian Teknologi Pertanian. Badan Penelitian dan Pengembangan Pertanian. Departemen Pertanian. Kendari. Hlm 5-6.

Sadhori, S.N. 1992. Budidaya Rumput Laut. Balai Pustaka. Jakarta. 110 hlm.

Setiadi. A dan U. Budihardjo, 2000. Rumput Laut Komoditas Unggulan. Grasindo Jakarta. Hlm 33-35.

Soegiarto, 1989. Rumput Laut (Algae), Manfaat, Potensi dan Usaha Budidaya. LON, LIPI, Jakarta.

Soegiarto. A., Sulistijo., Atmadja dan H. Mubarak., 1978. Rumput Laut (Algae), Manfaat, Potensi dan Usaha Budidaya. LON, LIPI, Jakarta. Hlm 83.

Sudiharjo. 2001. Teknologi Budidaya Rumput Laut. Balai Budidaya Laut. Lampung.

Sulistijo, 1985. Budidaya Rumput laut. LON.LIPI. Jakarta. Hlm 23-24.

Supit D.S. 1989. Karakterisitik Pertumbuhan dan Kandungan Rumput Laut Eucheuma cotinii (Doty) yang Berwarna Abu-abu, Coklat dan Hijau yang ditanam di Coba Lapangan Pasir Pulau Pari. (Skripsi) Institute Pertanian Bogor. Bogor. Hlm 15-18.

Wahyuni dan Mubarak. 1981. Budidaya Rumput Laut. Materi Lokakarya Budidaya Laut di Denpasar. Dirjen Perikanan dan UNDP/FAO. 12 hal.

Winarno, F.G., 1996. Teknologi Pengolahan Rumput Laut. Pustaka Sinar Harapan Jakarta. hlm 99-100.

Yunizal, Murtini JT, Utomo BS, Suryaningrum TH. 2000. Teknologi Pemanfaatan Rumput Laut. Jakarta: Pusat Penelitian dan Pengembangan Ekplorasi Laut dan Perikanan. hlm 1-11.

Yusuf M.I. 2004. Produksi, Pertumbuhan dan Kandungan Karaginan Rumput Laut Kappaphycus alvarezii (Doty) Doty (1988) yang Dibudidayakan Dengan Sistem Air Media dan Tallus Benih Yang Berbeda. (Disertasi) Program Pasca Sarjana Universitas Hasanudin, Makassar. Hlm 13-15.

Zatnika A, dan Wisman., 2006. Teknologi Budidaya Rumput Laut. Makala Pada Seminar Pekan Aquakulture V. Tim Rumput Laut BPP Teknologi Jakarta, Jakarta Http: //www.fao.org/docrep/field/003/AB882E/AB882E/Artikel. Diakses tanggal 7 januari 2008. Hlm 15 (Everhart et al., 1979; Kordi 2008). 